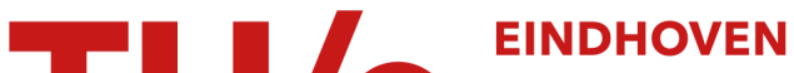 \\ UNIVERSITY OF \\ TECHNOLOGY
}

\section{Classical aspects of quantum spin chains (abstract)}

Citation for published version (APA):

Lemmens, L. F., De Jonge, W. J. M., \& Kopinga, K. (1990). Classical aspects of quantum spin chains (abstract). Journal of Applied Physics, 67(9), 5618. https://doi.org/10.1063/1.345904

DOI:

10.1063/1.345904

Document status and date:

Published: 01/12/1990

\section{Document Version:}

Publisher's PDF, also known as Version of Record (includes final page, issue and volume numbers)

\section{Please check the document version of this publication:}

- A submitted manuscript is the version of the article upon submission and before peer-review. There can be important differences between the submitted version and the official published version of record. People interested in the research are advised to contact the author for the final version of the publication, or visit the $\mathrm{DOI}$ to the publisher's website.

- The final author version and the galley proof are versions of the publication after peer review.

- The final published version features the final layout of the paper including the volume, issue and page numbers.

Link to publication

\section{General rights}

Copyright and moral rights for the publications made accessible in the public portal are retained by the authors and/or other copyright owners and it is a condition of accessing publications that users recognise and abide by the legal requirements associated with these rights.

- Users may download and print one copy of any publication from the public portal for the purpose of private study or research.

- You may not further distribute the material or use it for any profit-making activity or commercial gain

- You may freely distribute the URL identifying the publication in the public portal.

If the publication is distributed under the terms of Article $25 \mathrm{fa}$ of the Dutch Copyright Act, indicated by the "Taverne" license above, please follow below link for the End User Agreement:

www.tue.nl/taverne

Take down policy

If you believe that this document breaches copyright please contact us at:

openaccess@tue.nl

providing details and we will investigate your claim. 


\section{Classical aspects of quantum spin chains (abstract)}

L. F. Lemmens, W. J. M. de Jonge, and K. Kopinga

Citation: Journal of Applied Physics 67, 5618 (1990); doi: 10.1063/1.345904

View online: https://doi.org/10.1063/1.345904

View Table of Contents: http://aip.scitation.org/toc/jap/67/9

Published by the American Institute of Physics

\section{Ultra High Performance SDD Detectors}

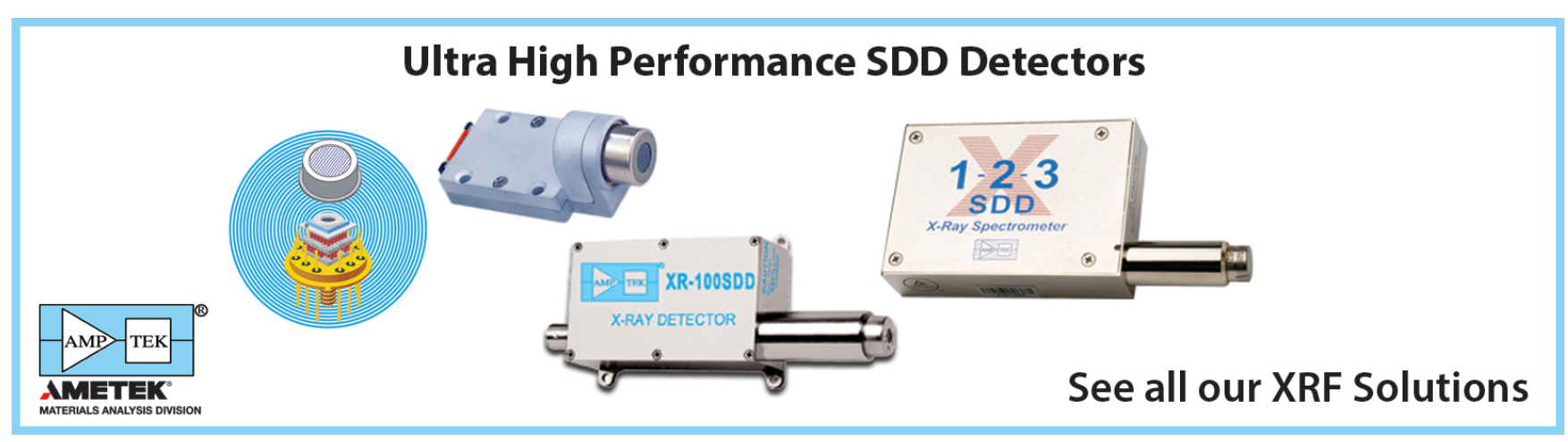




\section{Classical aspects of quantum spin chains (abstract)}

\section{F. Lemmens}

Institute for Applied Mathematics, University of Antwerp (RUCA), Groenenborgerlaan 171, B-2020 Antwerpen. Belgium

\section{W. J. M. de Jonge and K. Kopinga}

Department of Physics, Eindhoven University of Technology, NL-5600 MB Eindhoven, The Netherlands

A variational estimate of the free energy of a quantum spin chain based on the stochastic behavior of the quantization axes is proposed. It allows a description of the nonlinear excitations and quantum spin waves within the same framework. For an easy-plane ferromagnet with an external field in the plane it reveals that the nonlinear excitations ( solitons) are predominantly described by the classical degrees of freedom. Considerable effort has been devoted to the theoretical description' and experimental verification of the existence of nonlinear excitations. In this field magnetic chain systems have played an important part. ${ }^{2}$ Chain systems with an easy-plane anisotropy, such as $\left(\mathrm{C}_{6} \mathrm{H}_{11} \mathrm{NH}_{3}\right) \mathrm{CuBr}_{3}(\mathrm{CHAB})$ and $\mathrm{CsNiF}_{3}$, which are subjected to a symmetry breaking field, were found to be soliton bearing. ${ }^{3}$ Theoretically the description of the nonlinear effect is based on the mapping of the spin dynamics on a sine-Gordon model. Further research ${ }^{4}$ indicated that the interpretation of the thermodynamical properties of real systems in terms of the sine-Gordon model required however quantum and anisotropy corrections. Since the dipolar interactions between the spins in the chain are considered to be negligible, the direction of the spin chain in configuration space with respect to any preferred direction in spin space does not enter explicitly in the Hamiltonian. This makes it interesting to define a site-dependent $z$ direction in spin space which makes an angle $\left(\Theta_{n}, \phi_{n}\right)$ with the $z$ direction in configuration space. The model Hamiltonian can then be written in terms of the spin operators defined with respect to the sitedependent quantization axis. The representation with equal quantization axis for all the sites is related to the representation with different quantization axes at each site by a rotation in spin space. The unitary transformation that describes the rotation contains the angles $\left(\Theta_{n}, \phi_{n}\right)$, which we have treated as random variables. Based on this observation we have proposed a new variational approach for the quantum spin chain. We will outline the main results here. A full account is published elsewhere. ${ }^{5}$ In our approach the free energy of the system can be separated in a quantum part and a classical part. The free energy $F$ of the chain is then approximated by an upper bound $F<F_{\mathrm{cl}}+F_{\mathrm{ym}}$, where $\beta F_{\mathrm{cl}}=-\ln \left[E\left(\exp -\beta V_{\mathrm{c})}\right)\right]$ and $\beta F_{\mathrm{ym}}=-\ln \operatorname{Tr}\left(\exp -\beta\left\langle H_{\mathrm{ym}}\right\rangle\right)$. The first part is a configurational classical free energy, depending on the choice of the probability distribution for the quantization axes via the expectation $E$. The second contribution is the free energy of a modified quantum chain, whose parameters are classical averages and can be obtained from the configurational classical free energy. For easy-plane ferromagnetic chains, the nonlinear excitations are comprised in the classical part, whereas the quantum part contains predominantly linear excitations. For those thermodynamical quantities that are insensitive to the contribution of the quantum excitations, the chain is thermodynamically equivalent with a classical sine-Gordon system. The out-ofplane corrections are incorporated in the quantum part of the free energy. This behavior is corroborated experimentally by measurements of the excess heat capacity of CHAB for different magnetic fields with the same in-plane component. 'The validity of our approach is, however, not restricted to easy-plane ferromagnetic chains. Also for more complex systems with, for example, an orthorhombic or helical symmetry, the introduction of stochastic quantization axes can shed new light on some of the thermodynamical properties of these quantum systems in terms of their classical equivalent.

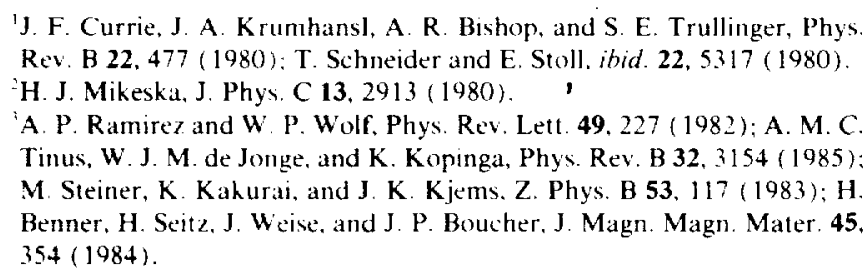

${ }^{4}$ H. C. Fogedby, K. Osano, and H. J. Jensen, Phys. Rev. B 34, 3462 (1986) R. Giachetti and V. Tognetti, ibid. 33, 7647 (1986); E. Magyari and H. Thomas, ibid. 25, 531 (1982): Phys. Rev. Lett. 51, 54 (1983); P. Kumar. Phys. Rev. B 25, 483 (1982)

L. F. Lemmens, K. Kopinga, and W. J. M. de Jonge, Phys. Rev. Lett. 63, 5 (1989)

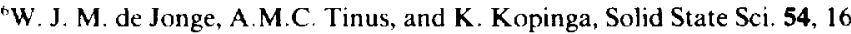
(1984). 